\title{
Akut Hepatit B Virüsü Infeksiyonlarının ve Kronikleșme Oranlarının Retrospektif Analizi
}

\section{Retrospective Analysis of Acute Hepatitis B Virus Infections and Chronicity Rates}

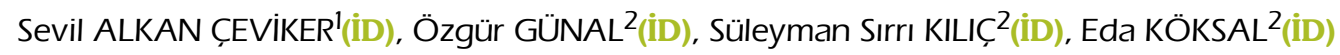 \\ ${ }^{1}$ Kütahya Sag̃ık Bilimleri Üniversitesi Evliya Çelebi Eg̃itim ve Araștırma Hastanesi, İnfeksiyon Hastalıkları ve Klinik Mikrobiyoloji \\ Klinig̃i, Kütahya, Türkiye \\ 2 Sag̃ılk Bilimleri Üniversitesi Samsun Eg̃itim ve Araștırma Hastanesi, İnfeksiyon Hastalıkları ve Klinik Mikrobiyoloji Klinig̃i, \\ Samsun, Türkiye
}

Makale atıfı: Alkan Çeviker S, Günal Ö, Kılıç SS, Köksal E. Akut hepatit B virüsü infeksiyonlarının ve kronikleşme oranlarının retrospektif analizi. FLORA 2020;25(2):213-9.

\section{ÖZ}

Giriş: Bu çalışmanın amacı erişkin akut hepatit B virüsü (HBV) infeksiyonu saptanan hastalarının klinik ve laboratuvar özellikleri ile bu infeksiyonu geçiren hastalarda kronikleşme oranlarını analiz etmektir.

Materyal ve Metod: Çalışmamızda Ocak 2010-Ekim 2018 tarihleri arasında, kliniğimizde akut HBV infeksiyonu tanısıla yatırılan 48 erişkin hastanın kayıtları retrospektif olarak incelendi. Hastalara ait, epidemiyolojik özellikler, demografik veriler, olası risk faktörleri, fizik muayene bulguları, uygulanan tedaviler ve mortalite/morbidite durumları, laboratuvar bulguları ve kronikleşme oranları değerlendirildi. Akut HBV infeksiyonu tanısı HBsAg ve anti-HBC IgM pozitifliği ile konuldu. Hastalarda HBV infeksiyonu kronikleşme durumlarının tespiti için, hastaların akut HBV infeksiyonu sonrasındaki altıncı ay sonuçlarına bakıldı.

Bulgular: Çalısmaya alınan 48 hastanın 35 (\%72.9)'i erkek, 13 (\%27.1)'ü kadın, yaş ortalaması $35.6 \pm 12.5$ (20-88) yıl idi. Erkeklerin yaş ortalaması $35.8 \pm 10.2$ (32-65), kadınların yaş ortalaması $35.1 \pm 11.2$ (21-88) idi. Olguların yaş dağı̆ımına göre incelemesinde, en fazla olgu sayısının 20-34 yaş aralığında olduğu saptanmıştır. Akut HBV infeksiyonu olan olguların diğer demografik özellikler incelendiğinde; bekar, ilköğretim mezunu ve ailede hepatit B öyküsü olanlarda infeksiyonun daha sık görüldüğ̈̈ tespit edilmiştir. Akut HBV olgularının altı aylık takipleri incelendiğinde; 3 (\%5.3) hastanın takiplerine gelmediği saptanmıştır. Bir (\%2.1) hasta fulminan hepatit nedeniyle eksitus olmuştur. Takiplerine gelen 45 akut HBV hastasının sonuçları incelendiğinde; transaminazları normal veya yüksek olan 4 (\%8.9) hastada kronik HBV infeksiyonu geliştiği, transaminazları normal olan 29 (\%64.4) hastada ilk dört ayda anti-HBs geliştiği, 2 (\%4.4) hastada altıncı ayda anti-HBs geliştiği yani toplam 31 (\%68.9) hastada anti-HBs geliştiği, öncesinde bilinen $H B s A g$ ve anti-HBC IgM pozitifliği olmayan transaminazları normal olan 11 (\%24.4) hastada ise anti-HBc IgG pozitifliği gelişip, HBsAg kaybı olduğu ancak anti-HBs gelişmediği saptanmıştır.

Sonuç: Çalısmamız akut HBV infeksiyonunun genç erkeklerde daha sık görüldüğünü ve kronikleşme oranının ülkemizde yapılan diğer çalışmalara göre yüksek olduğunu göstermiştir. Bu da hepatit B aşısının önemini bir kez daha göstermektedir.

Anahtar Kelimeler: Akut viral hepatit B infeksiyonu; Akut hepatit; Akut hepatit B virüsü infeksiyonunun kronikleşme oranı 


\title{
ABSTRACT \\ Retrospective Analysis of Acute Hepatitis B Virus Infections and Chronicity Rates
}

\author{
Sevil ALKAN ÇEVIKER', Özgür GÜNAL², Süleyman Sırrı KILIÇ², Eda KÖKSAL ${ }^{2}$
}

\author{
${ }^{1}$ Clinic of Infectious Diseases and Clinical Microbiology, Kutahya Health Sciences University Evliya Celebi Training and Research \\ Hospital, Kutahya, Turkey \\ ${ }^{2}$ Clinic of Infectious Diseases and Clinical Microbiology, Health Sciences University Samsun Training and Research Hospital, \\ Samsun, Turkey
}

\begin{abstract}
Introduction: The aim of this study was to analyze the clinical and laboratory features and the chronicity rates of hepatitis $B$ in adult
\end{abstract} acute hepatitis $B$ virus (HBV) patients.

Materials and Methods: In our study, the records of 48 adult patients hospitalize with the diagnosis of acute viral hepatitis $B$ in our clinic between January 2010 and October 2018 were retrospectively reviewed. Epidemiological characteristics, demographic data, possible risk factors, physical examination findings, mortality/morbidity, laboratory findings and chronicity rates were evaluated.

Results: Of the 48 patients included into the study, 35 (72.9\%) were males and 13 (27.1\%) were females, and the mean age was 35.6 \pm 12.5 (20-88) years. Mean age of the males and females was found respectively as $35.8 \pm 10.2(32-65)$ and $35.1 \pm 11.2$ (21-88). In the examination of the cases according to age distribution, the maximum number of cases was in the 20-34 age range. When other demographic features of cases with acute HBV infection are examined, it was found that it was more common among single, primary school graduates and in those with a family history of hepatitis B. When 6-month follow-up of acute HBV cases was examined, three (5.3\%) patients were not followed up. One (2.1\%) patient died due to fulminant hepatitis. When the results of 45 patients with AHB were examined, four (8.9\%) patients developed chronic HBV infection and 31 (68.9\%) patients anti-HBs in six months. In 11 (24.4\%) patients with normal transaminases rates and who were previously known having $H B s A g$ and anti-HBC IgM negativity, $H B s A g$ loss and anti-HBC IgG positivity developed, but anti-HBs did not develop.

Conclusion: Our study showed that acute HBV infection is more common in young men and the rate of chronicity is higher than other studies performed in our country. This has once again emphasized the importance of hepatitis $B$ vaccination.

Key Words: Acute viral hepatitis B infection; Acute hepatitis; Chronicity rate of hepatitis B virus infection

\section{GiRiș}

Hepatit $\mathrm{B}$ infeksiyonu tüm dünyada ve ülkemizde yaygın olarak göruilmekle beraber kroniklesebilen bir viral infeksiyondur. Dünya capında yaklașı 400 milyon insan hepatit B virüsü (HBV) ile infekte olmakta ve yilda yaklașik 1 milyon insan bu virüse bağlı gelisen karaciğer hastalıklarindan dolayı ölmektedir ${ }^{[1]}$. HBV infeksiyonunun doğal seyri oldukça değisken olup akut HBV infeksiyonu geçiren hastaların bir kısminda tam iyileșme görülürken, bir grup hastada ise hastalık kronikleșmekte veya tașııcılığa sebep olmaktadır. İnekte kișinin immün sisteminin gelișimi, immün yanıtın șiddeti ve virüse ait özellikler doğal seyri belirleyen faktörlerdir ${ }^{[2,3]}$. Akut $\mathrm{B}$ hepatiti, virüs ile karșlașıldıktan sonraki altı hafta ile altı ay arasında değișen inkübasyon döneminden sonra gelișmekte ve asemptomatik infeksiyondan, fulminant hepatite kadar değișebilen klinik tablolara yol açmaktadır. HBsAg pozitifliğinin altı aydan fazla devam etmesi halinde infeksiyonun kroniklestiği kabul edilir ${ }^{[4]}$.

$\mathrm{Bu}$ calısmanın amacı; erişkin akut HBV infeksiyonu geçiren hastaların klinik ve laboratuvar özellikleri ile hepatit B kronikleșme oranlarını analiz etmektir.

\section{MATERYAL ve METOD}

$\mathrm{Bu}$ çalıșma için hastanemiz etik kurulundan 30.10.2018 tarihinde TUEK 168-2018 GOKAEK/10-71 nolu kararla etik kurul onayı alındı.

Calısmamızda Ocak 2010-Ekim 2018 tarihleri arasında, kliniğimizde akut HBV infeksiyonu tanısıyla yatırılan 57 eriskin hastanın kayıtları retrospektif olarak incelendi. Hastalara ait, epidemiyolojik özellikler, demografik veriler (yas ve cinsiyet), süpheli temas öyküleri, kan transfüzyonu, operasyon öyküsü gibi olası risk faktörleri, fizik muayene bulguları, uygulanan tedaviler ve mortalite/morbidite durumları, laboratuvar bulguları ve 
kronikleșme oranları değerlendirildi. Ayrıca hemogram, anti-HBc IgM ve IgG, anti-HBs, $\mathrm{HBsAg}$, $\mathrm{HBeAg}$, anti-HBe, HBV-DNA ve biyokimyasal değerlerin [alanin aminotransferaz (ALT), aspartat aminotransferaz (AST), alkalen fosfataz (ALP), protrombin zamanı (PTZ), aktive parsiyel tromboplastin zamanı (aPTT), Uluslararası Düzeltme Oranı (INR)] sonuclarına bakıldı. Akut viral hepatit B infeksiyonu tanısı es zamanlı olarak HBsAg ve anti-HBc IgM pozitifliği ile konuldu. Hastalarda HBV infeksiyonu kroniklesme durumlarının tespiti için, hastaların akut HBV infeksiyonu sonrasındaki altıncı ay sonuclarına bakıldı. Esslik eden hepatit $C$ virüsü (HCV) ve insan immünyetmezlik virüsü (HIV) ko-infeksiyonu olanlar ile 18 yas altı olgular çalıșmaya dahil edilmedi. Ayrıca, öncesinde bilinen HBsAg pozitifliği olan üç hasta, immünsüpresif tedavi sonrası akut alevlenme gelisen bir hasta ile laboratuvar tetkiklerinde yüksek HBV-DNA (> 1 x $10^{5} \mathrm{IU} / \mathrm{mL}$ ), düșuik anti-HBc IgM (1000'de 1 titreden düsüuk) ve yüksek AFP (> $100 \mathrm{ng} / \mathrm{mL}$ ) değerleri saptanıp kronik HBV infeksiyonu olarak değerlendirilen bes hasta calıșmaya dahil edilmedi.

\section{İstatistiksel Analiz}

Verilerin istatistiksel analizinde IBM SPSS Statistics for Windows (Statistical Package for the Social Sciences, IBM Corp., Armonk, NY, ABD) programı kullanıld. Elde edilen verilere ait uygun tanımlayıcı istatistikler (ortalama, standart sapma, minimum, maksimum, yüzde) hesapland. Kategorik değișkenlerin karșılaștırmasında ki-kare ve Fisher-exact testleri kullanildi.

\section{BULGULAR}

Calıșmaya alınan 48 hastanın 35 (\%72.9)'i erkek, 13 (\%27.1)'ü kadın, yaș ortalaması 35.6 $\pm 12.5(20-88)$ yıl idi. Erkeklerin yas ortalaması $35.8 \pm 10.2$ (32-65), kadınların yas ortalaması $35.1 \pm 11.2(21-88)$ idi. Olguların yas dağılımına göre incelemesinde, en fazla olgu sayısının 20-34 yaș aralığında olduğu saptanmıștır (Șekil 1, Tablo 1). Akut HBV infeksiyonu olan olguların diğer demografik özellikler incelendiğinde; bekar, ilköğretim mezunu ve ailede hepatit $\mathrm{B}$ öyküsü olanlarda infeksiyonun daha sık görüldüğü tespit edilmiștir. Bașvuru sırasındaki en sik sikayetler; halsizlik ve iștahsızlık (\%91.2), ciltte sararma (\%63.2), idrar renginde koyulașma (\%61.4) ve kașintı (\%42.1) olaral belirlenmiștir (Tablo 1).

Calıșmaya alınan 48 hastanın akut hepatit $\mathrm{B}$ infeksiyonunun geliștiği yıllara göre incelemesinde, olgu sayısının en fazla 2011'de olduğu ve son üc yılda olgu sayısının oldukça az olduğu saptanmıștır (Șekil 2).

Tüm olgularda anti-HBc IgM değeri pozitifti. Olguların ilk bașvuru anındaki laboratuvar parametrelerinin incelemesinde; ortalama lökosit sayısı 6200/ $\mathrm{mm}^{3}\left(2000-18200 / \mathrm{mm}^{3}\right)$, hemoglobin $11.7 \mathrm{~g} / \mathrm{dL}$ (7.4-14.7 $\mathrm{g} / \mathrm{dL})$, trombosit say1s1 $159.000 / \mathrm{mm}^{3}$

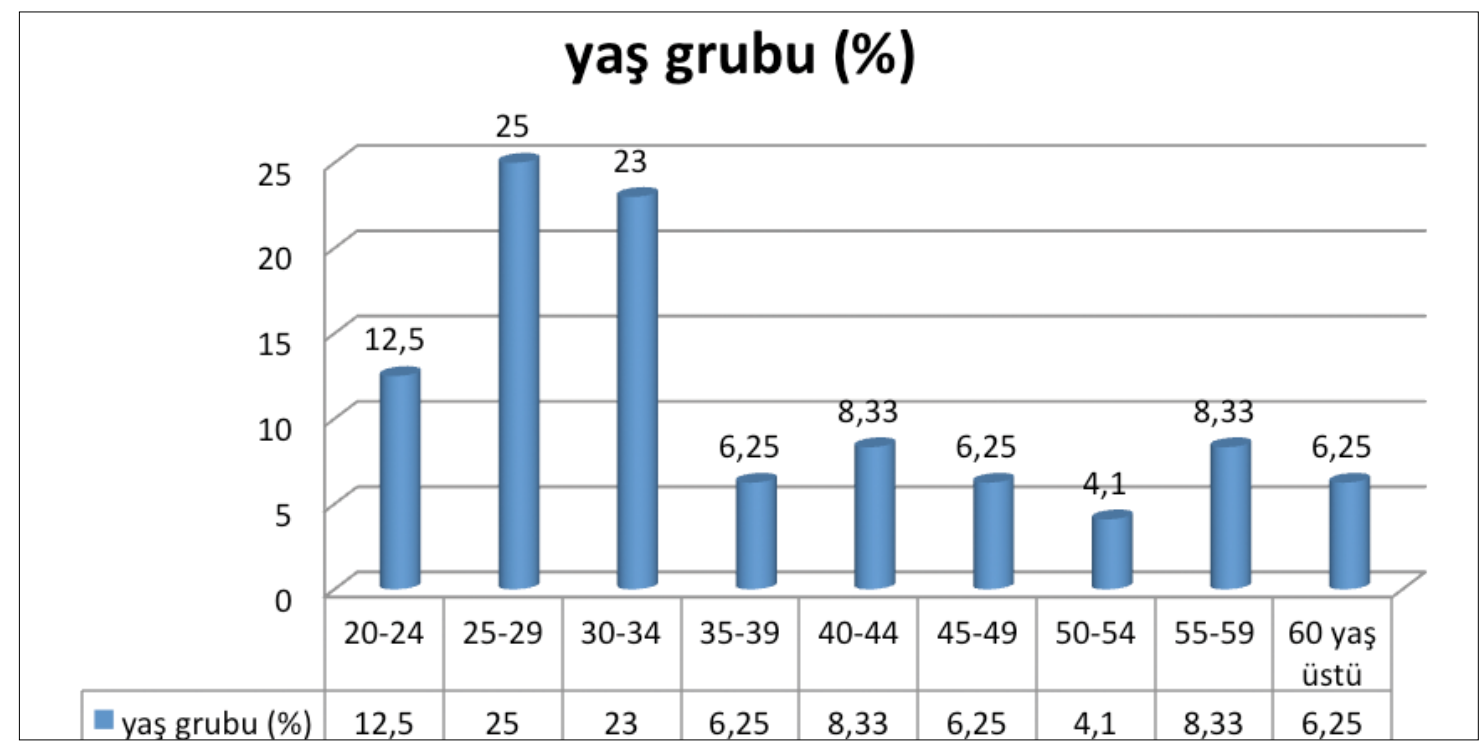

Şekil 1. Akut hepatit B olgularının yaş gruplarına göre dağılımı. 
Tablo 1. Akut hepatit B olgularının demografik özellikleri

\begin{tabular}{|c|c|c|}
\hline & Sayı & $\%$ \\
\hline \multicolumn{3}{|l|}{ Cinsiyet } \\
\hline Erkek & 35 & 72.9 \\
\hline Kadın & 13 & 27.1 \\
\hline \multicolumn{3}{|l|}{ Medeni durumu } \\
\hline Bekar & 29 & 60.4 \\
\hline Evli & 19 & 39.6 \\
\hline \multicolumn{3}{|l|}{ Eğitim durumu } \\
\hline Illköğretim & 31 & 64.6 \\
\hline Lise & 9 & 18.8 \\
\hline Üniversite & 8 & 16.7 \\
\hline \multicolumn{3}{|l|}{ Olası risk faktörleri } \\
\hline Ailede hepatit B öyküsü & 9 & 18.8 \\
\hline Riskli işte çalışma (sağlık çalışanı, bakımevi personeli) & 3 & 6.3 \\
\hline Şüpheli cinsel temas & 6 & 12.5 \\
\hline Perkütan yaralanma & 3 & 6.3 \\
\hline Damar içi ilaç kullanımı & 0 & 0 \\
\hline İnfekte kan ve vücut sıvıları ile mukozal ya da kütanöz temas & 5 & 10.4 \\
\hline Dövme yaptırma & 2 & 4.2 \\
\hline Hemodiyaliz tedavisi & 2 & 4.2 \\
\hline Kan transfüzyonu öyküsü & 6 & 12.5 \\
\hline Organ transplantasyonu & 0 & 0 \\
\hline Bilinmiyor & 12 & 25 \\
\hline \multicolumn{3}{|l|}{ Şikayet } \\
\hline Halsizlik ve iştahsızlık & 45 & 93.8 \\
\hline Ciltte sararma & 35 & 72.9 \\
\hline İdrar renginde koyulaşma & 34 & 70.1 \\
\hline Gaita renginde açılma & 10 & 20.8 \\
\hline Kusma & 10 & 20.8 \\
\hline Karın ağrısı & 16 & 17.5 \\
\hline Kaşıntı & 24 & 33.3 \\
\hline Ateş yüksekliği & 3 & 6.3 \\
\hline
\end{tabular}

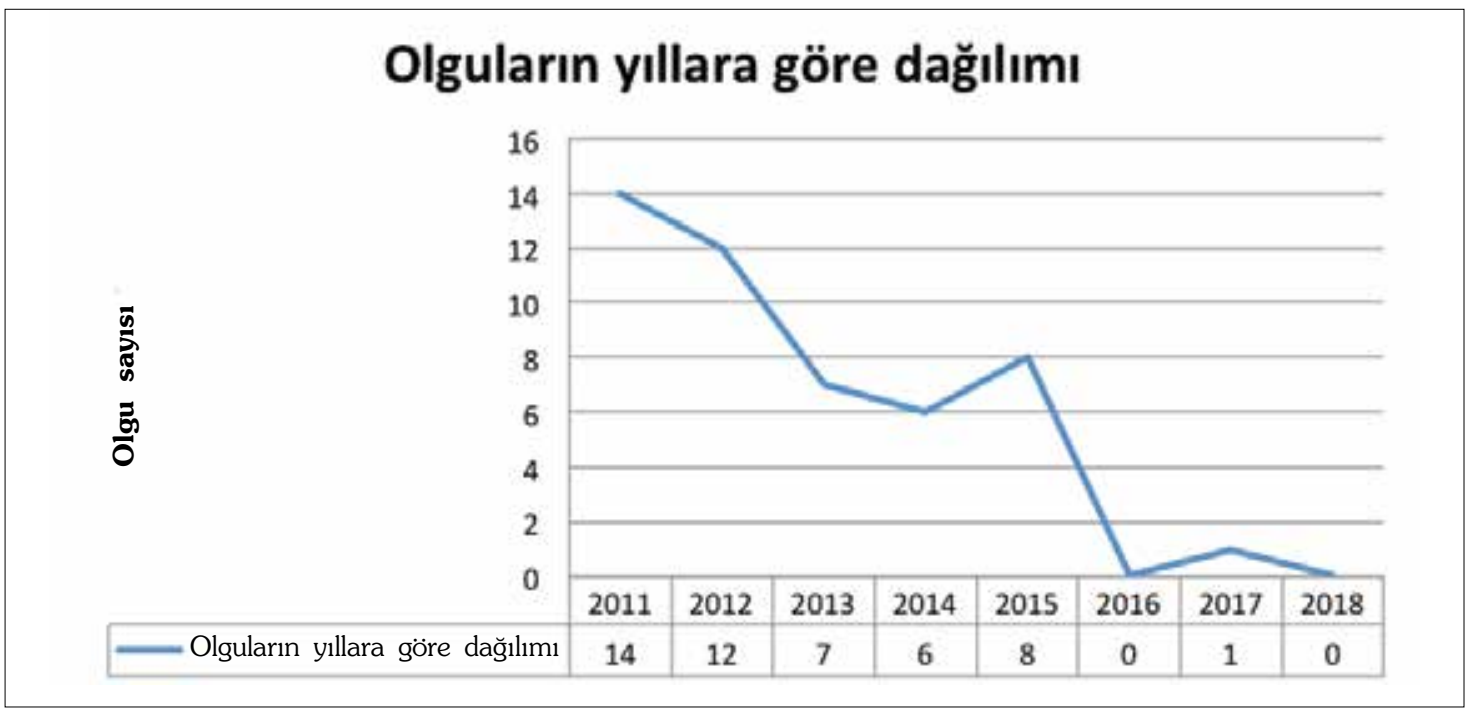

Şekil 2. Akut hepatit B olgularının yıllara göre dağılımı. 
Tablo 2. Akut HBV infeksiyonu olan olguların ortalama laboratuvar parametrelerinin incelenmesi

\begin{tabular}{ll} 
& Ortalama \\
\hline Beyaz küre & $6200 / \mathrm{mm}^{3}(2000-18200)$ \\
Hemoglobin & $11.7 \mathrm{~g} / \mathrm{dL}(7.4-14.7)$ \\
Trombosit sayısI & $159.000 / \mathrm{mm}^{3}(73000-434000)$ \\
AST & $1205 \mathrm{U} / \mathrm{L}(145-1840)$ \\
ALT & $2422 \mathrm{U} / \mathrm{L}(186-6753)$ \\
ALP & $453 \mathrm{U} / \mathrm{L}(92-767)$ \\
Total bilirubin & $10.8 \mathrm{mg} / \mathrm{dL}(1.2-35)$ \\
Direkt bilirubin & $8.6 \mathrm{mg} / \mathrm{dL}(0.8-24.3)$ \\
LDH & $925.4 \mathrm{U} / \mathrm{L}(168-1711)$ \\
PTZ & $20.9 \mathrm{sn}(11.1-43)$ \\
aPTT & $37.1 \mathrm{sn}(21-69)$ \\
INR & $3.5(1.1-5.0)$ \\
HBV-DNA (IU/mL) (ortalama) & 6.054 .684 \\
\hline ALT: Alanin aminotansfaz AST: Aspartat amis
\end{tabular}

ALT: Alanin aminotransferaz, AST: Aspartat aminotransferaz, ALP: Alkalen fosfataz, LDH: Laktat dehidrogenaz, PTZ: Protrombin zamanı, aPTT: Aktive parsiyel tromboplastin zamanı, INR: Uluslararası düzeltme oranı.

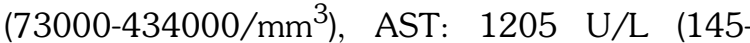
$1840 \mathrm{U} / \mathrm{L})$, ALT: $2422 \mathrm{U} / \mathrm{L}(186-6753 \mathrm{U} / \mathrm{L})$, ALP: $453 \mathrm{U} / \mathrm{L}$ (92-767 U/L), total bilirubin: $10.8 \mathrm{mg} / \mathrm{dL} \quad(1.2-35 \mathrm{mg} / \mathrm{dL})$, direkt bilirubin: $8.6 \mathrm{mg} / \mathrm{dL}(0.8-24.3 \mathrm{mg} / \mathrm{dL})$, laktat dehidrogenaz (LDH): $925.4 \mathrm{U} / \mathrm{L}$ (168-1711 U/L), PTZ: 20.9 sn (11.1-43 sn), aPTT: 37.1 sn (21-69 sn), INR: 3.5 (1.1-5.0) ve HBV-DNA ortalamas1: 6.054.684 IU/mL olarak saptanmıștır (Tablo 3).

Akut HBV olgularının altı aylık takipleri incelendiğinde; 3 (\%5.3) hastanın takiplerine gelmediği saptanmıstır. Bir (\%2.1) hasta fulminan hepatit nedeniyle eksitus olmuștur. Takiplerine gelen 45 akut hepatit $\mathrm{B}$ hastasının sonuçarı incelendiğinde; 4 (\%8.9)'ünde kronik HBV infeksiyonu geliștiği, 29 (\%64.4)'unda ilk dört ayda anti-HBs geliștiği, 2 (\%4.4)'sinde altınc1 ayda anti-HBs geliștiği yani toplam 31 (\%68.9) hastada anti-HBs geliștiği, öncesinde bilinen $\mathrm{HBsAg}$ ve anti-HBc IgM pozitifliği olmayan $11(\% 24.4)$ hastada ise anti-HBc IgG pozitifliği gelișip, HBsAg kaybı olduğu ancak anti-HBs gelișmediği saptanmıștır.

\section{TARTIȘMA}

Hepatit B virüsü karaciğer yetmezliği, siroz ve hepatoselüler kanser gelișme riskleri nedeniyle tüm dünyada olduğu gibi ülkemiz için de halen önemli sağllk sorunlarından biridir. HBV infeksi- yonu gelișimi için cinsiyet farkllığı risk faktörü olarak beklenmemekle birlikte yapılan bazı çlıșmalarda erkek hasta oranı, kadın hastalardan daha fazla saptanmıstır ${ }^{[5,6]}$. Ülkemizde yapılan bir çalıșmada ise HBV için cinsiyetin risk faktörü olmadığı bildirilmiștir ${ }^{[7]}$. Bizim çalıșmamızda erkek hasta oranı daha fazlaydı (erkek: \%72.9, kadın: \%27.1). Erkek hasta oranının fazla olması bu hasta grubunun daha sosyal aktif olmalarına ve riskli davranıșlara daha fazla maruz kalmalarına bağland.

Hastalarımızı yas grubuna göre incelediğimizde, en fazla olgu sayısının 20-34 yas aralığında olduğu saptandı. Halatoko ve arkadașlarının yapmıs oldukları bir calıșmada da benzer sekilde, akut viral hepatit olgularının yas aralığı 15-24 olarak genç hasta grubunda daha fazla olduğu saptanmistırir ${ }^{[8]}$.

Ülkemizde akut viral hepatit tanısı ile hastaneye yatırilan hastalarda halen en sik etkenlerden biri HBV'dir. HBV infeksiyonu için inkübasyon süresi 60-180 gündür. Bulas yolları cinsel temas, vertikal bulaş (anneden bebeğe doğum sırasında), horizontal bulaș (aile içi infekte bireylerin ortak malzeme kullanımı ve yakın teması), damar içi ilac kullanımı, dövme yaptıranlar, hemodiyalize girme, infekte kan ürünlerinin mukozal teması gibi kan 
temasıyla olmaktadır ${ }^{[9,10]}$. Bizim hastalarımızın 9 (\%18.8)'unda aile öyküsü mevcuttu, 3 (\%6.3) hasta riskli iște (sağlık çalıșanı ve bakım evi calıșanı) calıșıyordu ve 6 (\%12.5) hastanın suipheli cinsel temas öyküsü vardı. HBV ile temastan 1-12 hafta sonra kanda $\mathrm{HBsAg}$ seviyesi artar ve altı aydan uzun süre kanda $\mathrm{HBsAg}$ pozitifliği saptanması hastalığın kronikleștiğinin göstergesi olarak kabul edilir $^{[11]}$. Bizim hastalarımızın 4 (\%8.9)'ünde kronik HBV infeksiyonu geliștiği saptandı.

Tüm dünyada akut hepatit $\mathrm{B}$ insidansında önceki yıllara göre azalma olmakla birlikte, son 10 yılda HBV infeksiyonuna bağlı hastaneye yatıșların, hepatoselüler kanser olgularının ve mortalitenin arttığı bildirilmiștir. Bu durumun, 1991 yılında bașlatılmıș olan üniversal așı programının uygulamasının gecikmesine, tanısal yöntemlerin gelișmiș olmasına, global göclere ve HBV infeksiyonundaki tanı imkanlarının artıșına bağlı olabileceği bildirilmiștir ${ }^{[12]}$. Hepatit B așısı rutin așılama programına 1998 yılında giren ülkemizde Sağlık Bakanlığı verilerine göre özellikle akut hepatit B olgularında önceki yıllara göre belirgin azalma mevcuttur. Buna rağmen akut hepatit $B$, en fazla genc erișkin yas grubunda bildirilmektedir. Bunun en önemli nedeninin cinsel yolla bulașma olduğu düșünülmektedir ${ }^{[13-15]}$. Calıșmamızda da benzer sekilde, olgu sayısının gittikçe azaldığı saptandı.

Akut hepatit B tanısı ile bassvuran hastalarda bașlangıcta sikayetler nonspesifik olup; bulantı, kusma, grip benzeri sikayetler ve yorgunluk gözlenebilir. $\mathrm{Bu}$ dönem daha çok preikterik dönem olarak bilinir ve sarılık, koyu renkli idrar ve açlk renkli dıșkı gibi daha spesifik bulgular ikterik dönemde yani hastalığın bulașından yaklașık 60-180 gün sonra gözlemlenebilir ${ }^{[16]}$. Bizim hastalarımızın 45 (\%93.8)'inde hastalık bașlangıc anında halsizlik ve iștahsızlı sikayeti vardı. Otuz bes (\%72.9) hastada ciltte sararma, 34 (\%70.1) hastada idrar renginde koyulașma, 10 (\%20.8) hastada ise gaita renginde açlma șikayeti vardı.

Akut hepatit B infeksiyonunun seyri sirasında fulminan karaciğer yetmezliği gelișme oranının $\% 1$ 'in altında olduğu bildirilmektedir ${ }^{[17]}$. Akut viral hepatit sırasında gelișen fulminan hepatit konağın virüse karșı gösterdiği immün yanıttır ${ }^{[18]}$. Fulmi- nan karaciğer yetmezliği, ağır karaciğer hasarı sonucu gelișen karaciğer fonksiyon bozukluğu, koagülopati ve hepatik ensefalopatiyle gidebilen nadir ve mortalitesi yuiksek bir sendromdur ${ }^{[19]}$. Bizim de bir hastamızda fulminan hepatit $\mathrm{B}$ tablosu geliști ve mortal seyretti.

Akut HBV infeksiyonunun kroniklesme oran1nın erișkin yas grubunda \%1-10 civarında olduğu bildirilmekte olup HBV genotipine göre dünyada değișik oranlar bildirilmektedir $(20,21)$. Bu oranın erkeklerde daha yüksek olduğu bildirilmektedir. Calıșmamızdaki olguların \%72.9'u erkek olup, kronikleșme gelișen hastalardaki erkek/kadın oranı 3/1 idi. Calıșmamızda kronikleșme oranı \%8.9 olup bu oran oldukça yüksek saptand1. Retrospektif olan calıșmamızda HBV genotip calıșması yapilamadi.

\section{SONUÇ}

Calıșmamız akut HBV infeksiyonunun genç erkeklerde daha sık görüldüğünü ve kronikleșme oranının ülkemizde yapılan diğer calıșmalara göre yüksek olduğunu göstermiștir. Bu da özellikle 1998 yılından önce doğanlar ve așllanmamıs kisilerin akut hepatit B infeksiyonu için risk altında olduğundan, bu kișilerdeki hepatit B așısının önemini bir kez daha vurgulamıstır. Ayrıca akut hepatit B hastalarında HBV genotiplerinin araştırılması konularında çalıșmalara ihtiyaç olduğunu düșünmekteyiz.

\section{ETIK KURUL ONAYI}

$\mathrm{Bu}$ calıșma için hastanemiz etik kurulundan 30.10.2018 tarihinde TUEK 168-2018 GOKAEK/10-71 nolu kararla etik kurul onayı alındı.

\section{ÇIKAR ÇATIȘMASI}

Yazarlar bu makale ile ilgili herhangi bir çkar çatıșması bildirmemișlerdir.

\section{YAZAR KATKISI}

Anafikir/Planlama: SAC

Analiz/Yorum: SAÇ, ÖG

Veri sağlama: SAÇ, EK

Yazım: SAÇ, ÖG

Gözden Geçirme ve Düzeltme: ÖG

Onaylama: SSK 


\section{KAYNAKLAR}

1. Yu WH, Cosgrove $C$, Berger $C T$, Cheney PC, Krykbaeva $M$, Kim $A Y$, et al. ADCC-mediated CD56DIM NK cell responses are associated with early HBsAg clearance in acute HBV infection. Pathog Immun 2018;3:2-18.

2. Değertekin B. Hepatit B patogenezi, doğal seyri ve kliniği. Türkiye Klinikleri Gastroenterohepatoloji Özel Dergisi 2010;3(1):45-52.

3. Yapali S, Talaat N, Lok AS. Management of hepatitis B: our practice and how it relates to the guidelines. Clin Gastroenterol Hepatol 2014;12(1):16-26.

4. Sonsuz A. Kronik hepatit B ve C. Dobrucalı A, Tetikkurt C (editörler). Türkiye'de Sık Karşılaşılan Hastalıklar II. İstanbul: i.Ü. Cerrahpaşa Tıp Fakültesi Tıp Eğitimi Etkinlikleri Sempozyum Dizisi, 2007;58:79-90.

5. Özkurt Z, Erol S, Ertek M, Taşyaran MA. Akut viral hepatit olgularının değerlendirilmesi. Viral Hepatit Derg 2001;7:379-82.

6. Baig S. Gender disparity in infections of hepatitis $B$ virus. J Coll Physicians Surg Pak 2009;19(9):598-600.

7. Tekin Koruk S, Gürsoy B, Çalısır C, Koruk i, Şimşek Z, Yüksel $F$, et al. Hepatitis $B$ and hepatitis $C$ seroprevalence in the center of Sanliurfa province from southeastern anatolia region and related risk factors. Trakya Univ Tip Fak Derg 2010;27(4):367-72.

8. Halatoko WA, Patassi A, Yanogo P, Banla LI, Koba A, Issa Z, et al. Risk factors of hepatitis $B$ virus surface antigen carriage and serological profile of HBsAg carries in Lome Togo, 2016. BMC Public Health 2019;19(1):32.

9. Ayoola R, Larion S, Poppers DM, Williams R. Clinical factors associated with hepatitis $B$ screening and vaccination in high-risk adults. World J Hepatol 2019;11(1):86-98.

10. Lopez-Gatell H, Garcia-Garcia L, Echaniz-Aviles G, Cruz-Hervert $P$, Olamendi-Portugal $M$, Castaneda-Desales $D$, et al. Hepatitis $B$ seroprevalence in 10-25-year-olds in Mexico the 2012 national health and nutrition survey (ENSANUT) results. Hum Vaccin Immunother 2019;15(2):433-9.

11. Wilkins $T$, Sams $R$, Carpenter M. Hepatitis B: screening, prevention, diagnosis and treatment. Am Fam Physician 2019;99(5):314-23.

12. Kim WR, Ishitani MB, Dickson ER, et al. Rising burden of hepatitis $B$ in the United States: should the other virus be forgotten? Hepatology 2002;36:222.
13. Tosun S. Türkiye'de viral hepatit B epidemiyolojisi: yayınIarın meta-analizi. In: Tabak F, Tosun S (editörler). Viral Hepatit 2013. Ankara: Viral Hepatitle Savaşım Derneği, 2013:27-80

14. Sağlık Bakanlı̆̆ı. Sağlık istatistikleri Yıllığı 2012. Ankara: Sağlık Bakanlığı Yayın No. 917. 2013:1-164.

15. Akhan S, Aynıglu A, Cağatay A, Gönen I, Günal Ö, Kaynar $T$ ve ark. Kronik hepatit $B$ virusu infeksiyonunun yönetimi: Türk Klinik Mikrobiyoloji ve Infeksiyon Hastalıkları Derneği Viral Hepatit Çalışma Grubu Uzlaşı Raporu. Klimik Derg 2014;27:2-18.

16. Akbulut A. Akut viral hepatit. Leblebicioğlu H, Ulusoy S, Usluer $G$ (editörler). Güncel Bilgiler Işığında Antimikrobiyal Tedavi. Ankara: Bilimsel Tıp Yayınevi, 2015:231-9.

17. Lee WM. Acute liver failure. N Engl J Med 1993;329:186272.

18. Jacyra MR, Thomas HC. Viral hepatitis. In: Zuckerman AS, Thomas HC (eds). Viral Hepatitis. Scientific Basis and Clinical Management. Edinburg: Churchill Livingstone, 1993:185-205.

19. Aydın M, Aygen B, Mıstık R, Öncül O, et al. Fulminan hepatit B tedavisi: Türk Klinik Mikrobiyoloji ve Infeksiyon HastaIıkları Derneği Viral Hepatit Çalısma Grubu Uzlaşı raporu. 2013.

20. Ito $K$, Yotsuyanagi $H$, Sugiyama $M$, Yatsuhashi $H$, Karino $Y$, Takikawa Y, et al. Geographic distribution and characteristics of genotype $A$ hepatitis $B$ virus infection in acute and chronic hepatitis $B$ patients in Japan. J Gastroenterol Hepatol 2016;31(1):180-9.

21. Matsuura K, Tanaka Y, Hige S, Yamada G, Murawaki Y, Komatsu $M$, et al. Distribution of hepatitis $B$ virus genotypes among patients with chronic infection in Japan shifting toward an increase of genotype A. I Clin Microbiol 2009; 47:1476-83

\section{Yazıșma Adresi/Address for Correspondence}

\section{Uzm. Dr. Sevil ALKAN CEVIKER}

Kütahya Sağlık Bilimleri Üniversitesi

Evliya Celebi Eğitim ve Araștırma Hastanesi, İnfeksiyon Hastalıkları ve Klinik Mikrobiyoloji Kliniği, Kütahya-Türkiye

E-posta: s-ewil@hotmail.com 